Review Article

www.ijrap.net

\title{
ARSENICAL COMPOUNDS IN AYURVEDA MEDICINE: A PROSPECTIVE ANALYSIS
}

Ashok Kumar Panda ${ }^{1 *}$ and Jayram Hazra ${ }^{2}$

${ }^{1}$ Research Officer (S2), Director, National Institute of Ayurveda Drug Development, Sector-V, Bidhan nagar, Kolkota, India

${ }^{2}$ A Unit of Central Council for Research in Ayurveda Sciences, Department of AYUSH, Ministry of H\& FW, GOI, New Delhi, India

Received on: 02/08/12 Revised on: 12/10/12 Accepted on: 03/11/12

\author{
*Corresponding author \\ E-mail: akpanda_06@yahoo.co.in \\ DOI: 10.7897/2277-4343.03614 \\ Published by Moksha Publishing House. Website www.mokshaph.com \\ All rights reserved.
}

\section{ABSTRACT}

Haritala (Orpiment), Manashila (Realgar) and Gouripasana (White arsenic) are the three commonly used Arsenicals in Ayurveda and other codified traditional medicine of India for wide range diseases after Sodhana (Purification) and Marana (Calcification). Gouripasana (White arsenic) is now accepted in western medicine as first line chemotherapeutic agent against certain hematopoietic cancer. Malla sindura and Rasa Manikya are two derivatives of White arsenic and Orpiment respectively used in certain cases of cancer and solid tumor by the contemporary Ayurveda Practitioners and traditional healers of Northeast India. A systematic study on arsenical compounds in Ayurveda is not found as like Chinese traditional medicine, therefore a prospective study to analyze the different arsenicals used in Ayurveda, their purification, properties, formulation, pharmacology and therapeutics, toxicology as described in Ayurveda with modern understanding of biological responses, toxicology and detailed pharmacological studies were undertaken. The indications of Arsenicals in Ayurveda medicine are still remaining to be justified in the light of modern pharmacology. This study throws an idea where an Ayurveda clinician and patient can presume the risk in light of benefit.

KEY WORDS: Realgar, White arsenic, Malla sindura, Rasamaniya, solid tumor, malignancy

\section{INTRODUCTION}

Ayurveda (The Science of life) is becoming more and more popular as alternative and complementary medicine around the globe over recent years ${ }^{1}$. There have been increased numbers of case reports being published of toxic metals poisoning such as Lead, Mercury and Arsenic after the use of Ayurveda remedies ${ }^{2-4}$ which create a negative impact on public for the use of Ayurveda medicine ${ }^{5}$. The arsenical compounds have a long and remarkable history of pharmacological utilities and traditional practices ${ }^{6}$. The Arsenical compounds are intentionally added to the Ayurvedic formulations as main active ingredients or as auxiliary agent to assist the efficacy of herbal drugs. Clinical manifestation due to arsenic containing Ayurvedic medicines have also been reported from our country ${ }^{7}$. Various efficacy aspects and side effects of Arsenical compounds used in Ayurveda are scattered in classical texts of Ayurveda and modern literature ${ }^{8-11}$. Inorganic arsenic is now accepted in western medicine as first line therapeutic agent against certain hematopoietic cancers and other malignancies ${ }^{12}$. A systematic study on arsenical compounds in Ayurveda is not found as like Chinese traditional medicine, therefore a prospective study to analyze the different arsenicals used in Ayurveda, their purification, properties, formulation, pharmacology and therapeutics, toxicology as described in Ayurveda with modern understanding of biological responses, toxicology and detailed pharmacological studies was undertaken. The Indications of Arsenicals in Ayurveda medicine are still remaining to be justified in the light of modern pharmacology. This study throws a idea where an Ayurveda clinician and patient can presume the risk in light of benefit.

\section{Brief History of Arsenical in Medicines}

Arsenic is derived from Greek word arsenikon meaning "potent". It is used as a poison and therapeutic agent from the ancient times. Susruta narrated about arsenical compounds (Phenasma) as metallic poison before 2000B.C.The external uses of Orpiment and Realgar in skin diseases are described in Charak Samhita (400B.C). But the extensive uses of Arsenics in Ayurveda found after 8th century after the development of Rasa Sastra as many derivatives of Arsenicals are found in therapeutics. The uses of Arsenicals in Siddha and Unani System of Medicine are also found in India. In ancient Chinese medicines, the use of arsenic can be traced back to 200 B.C. in Shen Nong Ban Cao Jing, the first traditional Chinese medicine book. Hippocrates (460 to $377 \mathrm{BC}$ ) used orpiment $\left(\mathrm{As}_{2} \mathrm{~S}_{3}\right)$ and realgar $\left(\mathrm{As}_{2} \mathrm{~S}_{2}\right)$ as ulcer healing remedy. Aristotle (384 to $322 \mathrm{BC}$ ) and Pliny the Elder (23 to $79 \mathrm{AD}$ ) also wrote about the medicinal properties of the arsenicals. Galen (130 to 200 AD) commended a paste of arsenic sulphide for the treatment of ulcers. Paracelsus (1493 to 1541) used elemental arsenic extensively. He is quoted as saying 'All substances are poisons ... The right dose differentiates a poison and a remedy $^{13}$. Pedanius Dioscorides (40-90 AD), a Greek physician famous for writing a five volume book De Materia Medica that is a precursor to all modern pharmacopoeias, used orpiment as a depilatory. During the 16th and 17th centuries, Jean de Gorris, a French physician, used arsenic as a sudorific, Angelus Salva against the plague, Rosinus Lentilius and Friceius as a treatment for malaria. Arsenicals were also largely used for medicinal purposes in traditional Chinese medicine in the regimens for psoriasis, rheumatic diseases and 
syphilis. The three commonly used Arsenicals in Ayurveda are - Orpiment, Realgar and White arsenic. These has been used in more than 100 formulation in Ayurveda medicine for skin diseases, Cough, Bronchitis, Asthma, Piles, Fistula, Sinus, Irregular fever, non-heal ulcer, Epilepsy, Elephantiasis and Aphrodisiac. Arsenic trioxide is now becoming a very promising hemotherapeutic agent in Western medicine to treat acute promyelocytic leukemia (APL) and possibly other malignancies ${ }^{14}$. There is a history of its toxic effect also. Due to its use by the ruling class to murder one another and its incredible potency and discreetness, arsenic has been called the Poison of Kings and the King of Poisons. Notable deaths by Arsenic poisoning include King George III of Great Britain, Napoleon Bonaparte, and American explorer Charles Francis Hall ${ }^{15}$.

\section{Brief Chemistry of Arsenic}

Arsenic (atomic number 33, atomic weight 75) is a member of the nitrogen group in the periodic table. It is classified as a transitional element or metalloid. Arsenic can exist in three different valence states: elemental arsenic (zero oxidation state); trivalent; or pentavalent arsenic. It forms alloys with metals and also readily reacts with carbon, oxygen and hydrogen, forming covalent bonds. The toxicity of an arsenical varies with the valence state (trivalent are more toxic than pentavalent compounds), the physical state of the compound, and the rates of absorption and elimination. Elemental arsenic (the metalloid) is non-toxic even if eaten in substantial amount ${ }^{16}$. Inorganic forms of arsenic are more toxic than organic forms. Arsenic has been shown to produce oxidative stress. Arsenic trioxide has been shown to cause a significant prolongation of cardiac action potential duration at many levels of re-polarization producing conduction delay and increased triangulation. Electrolyte imbalance appears to enhance this toxicity. The drug appears to inactivate endothelial nitric oxide synthesis, leading to a reduction in production and bioavailability of nitric oxide. It also has been associated with inducing/accelerating atherosclerosis, increasing platelet aggregation and reducing fibrinolysis ${ }^{17}$. In addition, an apparent link exists between arsenic exposure and gestational diabetes and potential long-term effects on the infants born to mothers consuming arsenic-contaminated water among other during pregnancy ${ }^{18}$.

\section{AYURVEDA AND ARSENICAL COMPOUNDS}

Haritala (Orpiment), Manashila (Realgar) and Gouripasana (White arsenic) are the three commonly used Arsenicals in Ayurveda used in wide range diseases (Table 1). Haritala (Orpiment) and Manashila (Realgar) come under Uparasa and Gouripasana (White arsenic) comes under Sadharana Rasa as per the Ayurveda Rasa sastra (Alchemy). Malla sindura and Rasa Manikya are two derivatives of White arsenic and Orpiment respectively used in certain cases of cancer by the contemporary Ayurveda Practitioners. The Pharmacological properties of drug in Ayurveda is based on Rasa (Taste), Guna (Properties) Virya (potency) and Vipaka (final digestive Product) as the main causative factor of diseases are Sheeta (cold), Snigdha (Unctuous),
Ushana (hot) and Rukshya (not unctuous). Anupana is also important in Ayurveda practice which is the materials/vehicle taken with or after the ingestion of Ayurveda medicine. The dose, Pharmacological properties and Anupana of Arsenicals used in Ayurveda are pointed out (Table 2). Many toxic metals are used in Ayurveda after Sodhana (Purification) and Marana (Calcination). Sodhana (Purification) is a method of triturating herbs and animal's product and heating of metals to metamorphosed into herbo-mineral. It is a process to convert Inorganic materials to Organic compound for better absorption, assimilation, reduce toxicity and to enhance the medicinal properties ${ }^{19}$. Ayurveda well defined the toxic effect after ingestion of Arsenicals without proper purification and Purification methods of Arsenical Compounds (Table 3).

\section{Absorption, Metabolism and toxicology of Arsenicals used in Ayurveda Medicine}

All arsenical compounds used in Ayurveda drugs are absorbed in gastrointestinal system. Haritala (Orpiment) has low solubility in water. Orpiment dissolution is kinetically slow and under anaerobic conditions; an increase in $\mathrm{pH}$ increases Orpiment dissolution rate $^{20}$. Orally administrated orpiment is poorly absorbed and over $82 \%$ is found in feces within 3 days. Urinary arsenic metabolites from oral exposure are mainly DMA, suggesting that biotransformation of absorbed orpiment is in the body itself. Manashila (Realgar) has more low solubility than Haritala (orpiment) and $4 \%$ is bioavailable in physiologic gastric juice or intestinal fluid. Oral administration of realgar in rats $(150 \mathrm{mg} / \mathrm{kg}$, daily for 5 weeks) showed that only a small portion of arsenic was absorbed and reaches the blood $(45 \mathrm{mg} / \mathrm{ml})$, Lung $(5.4 \mathrm{mg} / \mathrm{g})$, spleen $(5.2 \mathrm{mg} / \mathrm{g})$ and liver $(2.9 \mathrm{mg} / \mathrm{g})^{21}$. Arsenic trioxide, purified from mineral arsenolite, highly water soluble and well absorbed after oral dose. Pharmacokinetics studies in human being showed that after arsenic trioxide infusion (10mg/day I.V) for 90 days for cancer chemotherapy, blood arsenite levels reaches steady state of 5.5 to $7.3 \mathrm{M}^{22}$. Orally administrated Arsenic trioxide can achieve similar mean plasma level as like Intravenous route which indicate high absorption from GI tract. The bioavailability of Haritala, Manashila and Gouripasana are illustrated with the findings in various systems (Table 4).

The metabolism of all arsenical compounds used in Ayurveda drugs are in two phase's i.e reduction and Oxidative methylation reaction. Oxidative methylation reaction is a process of conjugation in which arsenicals are sequentially methalated to form Mono methylarsononous acid (MMA), Di methylarsonic acid (DMA) and finally Trimethylarsonic acid (TMA) products using S- adendsyl methionine (SAM) as methyl donor and glutathione (GSH) as an essential co-factor ${ }^{23}$. The MMA and DMA are readily excreted in urine.

The $\mathrm{LD}_{50}$ of Arsenicals used in Ayurveda medicine was discussed with their available acute and chronic toxicological studies (Table 5). The $\mathrm{LD}_{50}$ of Haritala is more than the Manashila. The oral $\mathrm{LD}_{50}$ of Gouripasana (Arsenic trioxide) is $3.2 \mathrm{mg} / \mathrm{kg}$, a difference of 100 fold compared with Manashila. Intraperitoneal administration of Haritala was negative in mouse bone marrow cell 
micronucleus assay, despite the resultant of high blood arsenic levels $(900 \mathrm{ng} / \mathrm{ml})$. Intratrachial administration of orpiment $(3.75 \mathrm{mg} / \mathrm{kg}$ once a week for 15 wees) in hamsters did not increase the lungs tumor incidence. The literature of Ayurveda does not identified toxicity after the use of purified Haritala.

Manashila (Realgar) is widely used externally and internally in Ayurveda and other traditional system of India. In general, they are safe with a very few reports on their toxicities and adverse effects. In humans chronically taking realgar-containing Ayurveda medicines at higher doses, mild gastrointestinal discomfort may occur; however, no myelosuppression was observed. The major concern for high dose and long-term realgar treatment in humans is cardiac toxicity, manifested as prolonged QT wave, which is a dose-dependent finding. However, this side effect is tolerable and reversible. Liver is a major target organ of long-term arsenic toxicity, and the longterm use of realgar in humans may cause fatty liver; however, neither liver fibrosis nor dysfunction was observed. However, the well designed dose- and timerelated toxicology studies are required to critically evaluate the toxicology profiles of realgar-containing Ayurveda medicines.

Gouripasana (Arsenic trioxide) is highly toxic compared to Haritala and Manashila. Short-term toxicity of arsenic trioxide is the major concern in the use of this agent to against malignancies, and at least three sudden deaths have been reported. Prompt chelation treatment is beneficial for short-term arsenic trioxide intoxication. The clinical doses of arsenic trioxide (5-10 mg i.v.) could induce cardiac injury, such as QT prolongation, arrhythmias, and, in extreme cases, cardiac arrest. Other adverse effects include skin lesions; gastrointestinal symptoms, neuropathy, and liver dysfunction are reported with long term arsenic trioxide use and are generally tolerable and reversible. In a long-term study in rabbits, arsenic trioxide at a dose of $0.2 \mathrm{mg} / \mathrm{kg}$ i.v. for 30 days produced cardiac injury, with alterations in cardiac function. These adverse effects are reversible after the termination of arsenic trioxide treatment. Possible secondary cancers have not been reported in patients receiving arsenic trioxide.

\section{Biological Responses to Arsenic Compounds}

Arsenicals compound has been used to control the blood counts of the patient with hematological malignancies. There is some observation of the treatment of various solid tumors by contemporary Ayurveda practitioners such as in Nasal polyps, Hemorrhoid and Elephantiasis ${ }^{21}$. It may be due to the induction of apoptosis. The mechanism of Arsenic -induced cell death is well understood in the application of $\mathrm{AS}_{2} \mathrm{O}_{3}$, which is a potent cytotoxic and antitumor activies in vitro and vivo. An important initial cellular event that occurs during treatment of target cells with $\mathrm{As}_{2} \mathrm{O}_{3}$ involves elevation of ROS. Such generation of ROS appears to be regulated, at least in part, by activation of NADPH oxidase and NO synthase isozymes. Also, arsenic-containing compounds are potent modulators of the thioredoxin system that includes thioredoxin, thioredoxin reductase, and NADPH . The thioredoxin system controls, to a large extent, intracellular redox reactions, regulates apoptosis, and protects cells from stress damage, and the ability of arsenic-containing compounds to target and block thioredoxin reductase may be important in the induction of its pro-apoptotic effects.

Overproduction of ROS is linked to the induction of apoptosis by $\mathrm{As}_{2} \mathrm{O}_{3}$. Accumulation of hydrogen peroxide $\left(\mathrm{H}_{2} \mathrm{O}_{2}\right)$ leads to decreases in the mitochondrial membrane potential, resulting in cytochrome $c$ release and activation of the caspase cascade. This appears to be a common mechanism of induction of cell death in diverse cellular backgrounds $^{22}$. Arsenic compounds frequently target element $\mathrm{s}$ and oncogenes selectively expressed in certain malignancies.

The poly herbo-mineral compounds are comparatively safe, when appropriately manufactured and consumed as per directed instructions. It also re-emphasizes that the mere presence of a chemical compound of metallic origin does not contribute to the toxicity of the finished product as the standard manufacturing process inflicts intense changes and components of herbal origin after sequential reactions with diverse components of processing is responsible for the therapeutic action ${ }^{23-24}$.

Table 1: Natural Arsenic compound in Ayurveda Medicine

\begin{tabular}{|c|c|c|c|}
\hline Ayurveda Name & Popular name & Chemical formula & Therapeutic Uses in Ayurveda \\
\hline Haritala & Orpiment & $\mathrm{AS}_{2} \mathrm{~S}_{3}$ & $\begin{array}{c}\text { All types of Skin diseases, Irregular fever, Fistula in Ano, Piles and sinus, } \\
\text { Non heal ulcer, Cough, cold, Bronchitis, Aphrodisiac, Syphilis, Cancer }\end{array}$ \\
\hline Manashila & Realgar & $\mathrm{AS}_{3} \mathrm{~S}_{4}$ & $\begin{array}{c}\text { Anorexia, Wasting diseases like- cancer and Tuberculosis, Chronic fever, } \\
\text { Vitiligo, Infectious diseases. }\end{array}$ \\
\hline Gouripasana & White Arsenic & $\mathrm{AS}_{2} \mathrm{O}_{3}$ & $\begin{array}{c}\text { Syphilis, Elephantiasis, Anemia, Psoriasis, Asthma, Osteoarthritis, } \\
\text { Spleenomegaly, Impotency, cancer }\end{array}$ \\
\hline
\end{tabular}

Table 2: Pharmacological Properties as per Ayurveda

\begin{tabular}{|c|c|c|c|}
\hline Name Of the Arsenicals & Therapeutic Dose & Pharmacological Properties & $\begin{array}{c}\text { Anupana } \\
\text { ( Vehicle) }\end{array}$ \\
\hline Haritala $\left(\mathrm{AS}_{2} \mathrm{~S}_{3}\right)$ & $30-60 \mathrm{mg}$ & $\begin{array}{c}\text { Rasa- Katu, Guna-Ushana, Snigdha } \\
\text { Virya- Ushana and Vipaka- Katu }\end{array}$ & $\begin{array}{c}\text { Honey, ghee, milk and as per disease } \\
\text { condition }\end{array}$ \\
\hline Manashila $\left(\mathrm{AS}_{3} \mathrm{~S}_{4}\right)$ & $15-30 \mathrm{mg}$ & $\begin{array}{c}\text { Rasa- Katu, Guna-Ushana, Snigdha } \\
\text { Virya- Ushana and Vipaka- Katu }\end{array}$ & $\begin{array}{c}\text { Honey, ghee, milk and decoction as } \\
\text { per disease condition. }\end{array}$ \\
\hline Gouripasana $\left(\mathrm{AS}_{2} \mathrm{O}_{3}\right)$ & $1-4 \mathrm{mg}$ & $\begin{array}{c}\text { Rasa- Katu, Guna-Ushana, Snigdha } \\
\text { Virya- Ushana and Vipaka- Katu }\end{array}$ & $\begin{array}{c}\text { Honey, ghee, milk, sugar and } \\
\text { decoction as per disease condition }\end{array}$ \\
\hline
\end{tabular}


Table 3: Well defined toxic effect and Purification methods of Arsenical Compounds as narrated in Ayurveda

\begin{tabular}{|c|c|c|}
\hline Name Of the Drug & Toxic effect & $\begin{array}{l}\text { Purification method } \\
\end{array}$ \\
\hline $\begin{array}{l}\text { Haritala } \\
\left(\mathrm{AS}_{2} \mathrm{~S}_{3}\right)\end{array}$ & $\begin{array}{l}\text { Serious Skin manifestation, Burning, Wasting } \\
\text { diseases, Neurological Manifestation }\end{array}$ & $\begin{array}{l}\text { Swedana (Boiling) mixed with juices of Kusmanda (Bottle } \\
\text { guard)/Aloe vera/ lemon for three hours. }\end{array}$ \\
\hline $\begin{array}{l}\text { Manashila } \\
\left(\mathrm{AS}_{3} \mathrm{~S}_{4}\right)\end{array}$ & $\begin{array}{l}\text { Asmari (stone), Dysuria, Anoxia and Skin } \\
\text { manifestation. }\end{array}$ & $\begin{array}{c}\text { Seven times Bhabana (triturating) in Agashi patra swarasa/ lemon } \\
\text { /ginger juices. }\end{array}$ \\
\hline $\begin{array}{c}\text { Gouripasana } \\
\left(\mathrm{AS}_{2} \mathrm{O}_{3}\right)\end{array}$ & Burning, skin manifestation and death & $\begin{array}{l}\text { Swedana (Boiling) with milk for three hours or putting inside bitter } \\
\text { guard and boiling for three hours. }\end{array}$ \\
\hline
\end{tabular}

Table 4: Pharmacokinetics Studies of Arsenical compounds in Ayurveda Practice

\begin{tabular}{|c|c|c|}
\hline Name Of the Drug & Bioavailability & System and findings \\
\hline Haritala & Low & In vitro- Dissolution increase with pH increases \\
$\left(\mathrm{AS}_{2} \mathrm{~S}_{3}\right)$ & Low GI absorption & Hamster- $80 \%$ in feces, DMA in urine \\
\hline Manashila & $4 \%$ & Human-MMA and DMA in urine \\
$\left(\mathrm{AS}_{3} \mathrm{~S}_{4}\right)$ & Low & Rat-Blood $>$ lungs $>$ heart $>$ spleen $>$ Liver $>$ kidney \\
& Nano -particle & Cell and rat- Increase bioavailability \\
\hline Gouripasana $\left(\mathrm{AS}_{2} \mathrm{O}_{3}\right)$ & High & Human-Oral equals to Intravenous bioavailability \\
\hline
\end{tabular}

\begin{tabular}{|c|c|c|c|}
\hline Name Of the Drug & Short term Toxicity & Long term toxicity & Remark \\
\hline $\begin{array}{l}\text { Haritala } \\
\left(\mathrm{AS}_{2} \mathrm{~S}_{3}\right)\end{array}$ & $\mathrm{N} / \mathrm{A}\left(\mathrm{LD}_{50}=6.4 \mathrm{gm} / \mathrm{kg}\right)$ & $\begin{array}{l}\text { Negative in micronucleus assay } \\
\text { Negative in lungs tumor formation, }\end{array}$ & High level in blood. \\
\hline $\begin{array}{l}\text { Manashila } \\
\left(\mathrm{AS}_{3} \mathrm{~S}_{4}\right)\end{array}$ & $\mathrm{N} / \mathrm{A}\left(\mathrm{LD}_{50}=3.2 \mathrm{gm} / \mathrm{kg}\right)$ & $\begin{array}{l}\text { Cutaneous manifestation } \\
\text { Mild G.I discomfort } \\
\text { Fatty liver, but no fibrosis } \\
\text { Prolonged QT }\end{array}$ & $\begin{array}{l}\text { Adverse effect } \\
\text { Tolerable }\end{array}$ \\
\hline $\begin{array}{c}\text { Gouripasana } \\
\left(\mathrm{AS}_{2} \mathrm{O}_{3}\right)\end{array}$ & $\begin{array}{c}\text { Sudden death, poisoning } \\
\left(\mathrm{LD}_{50}=32.29 \mathrm{mg} / \mathrm{kg}\right)\end{array}$ & $\begin{array}{l}\text { Cardiac, skin and GI effect, } \\
\text { No secondary cancer report }\end{array}$ & Dose dependant, Tolerable \\
\hline
\end{tabular}

Table 6: Formulation and Uses of Arsenic Compounds based on Ayurveda Pharmacopoeia

\begin{tabular}{|c|c|c|}
\hline \multicolumn{2}{|c|}{ Table 6: Formulation and Uses of Arsenic Compounds based on Ayurveda Pharmacopoeia } \\
\hline Name & Ayurveda formulation & Therapeutics Uses \\
\hline $\begin{array}{c}\text { Haritala } \\
(\text { Orpiment }) \\
\mathrm{AS}_{2} \mathrm{~S}_{3}\end{array}$ & $\begin{array}{c}\text { Kanaksheera taila, Kasturivarava rasa, Krimikastanal rasa, Gulma kalanta rasa, Chandakeswar rasa, } \\
\text { Tala bhasma, Talakeswar rasa, Tala Sindura rasa, Srungarabhra rasa, Nityananda rasa, Manmathabra } \\
\text { rasa, Raktapitantaka rasa, Rasamanikya, Rasendragutika, Vatagajankusa rasa, Vatarktantaka rasa, } \\
\text { Betalal rasa, Sannipatabhairabha, Samirapannga rasa, Sarbeswaree rasa }\end{array}$ & Skin diseases \\
\hline $\begin{array}{c}\text { Manashila } \\
\text { (Realgar) } \\
\mathrm{AS}_{2} \mathrm{~S}_{2}\end{array}$ & $\begin{array}{c}\text { Adhorsrungha rasa, Lalangnibhairav rasa, Kalanala rasa, Kulabadhu rasa, Krimikastalana rasa, } \\
\text { Krimibinashana rasa, Krimihara rasa, Kshyakesari rasa, Gadamurari rasa, Trayalokachintamoni, } \\
\text { Parnakhandeswar, Bhaktabipaka rasa, Manashiladi grita, Manashiladya anjan, Manashiladi varti, } \\
\text { Mrutsanjeebani, Mrutautthapana rasa, Rasendra gutika Br, Swasa kuthar Rasa, Snesmakalantaka rasa, } \\
\text { Manashiladi lepam }\end{array}$ & Skin diseases \\
\hline $\begin{array}{c}\text { Gouripasana } \\
\mathrm{AS}_{2} \mathrm{O}_{3}\end{array}$ & $\begin{array}{c}\text { Ardhababhedahara yoga, Kalanala Rasa, Chandeswar Rasa, Tandabarilauha, Nityoditarasa, Malla vati, } \\
\text { Mallasindura, Badabanala rasa, Shankhavishodaya rasa, Sannipatavairaba Rasa, Samirapannaga rasa, } \\
\text { Suchikabhorana rasa }\end{array}$ & $\begin{array}{c}\text { Hemi crania, } \\
\text { Headache, sinusitis }\end{array}$ \\
\hline
\end{tabular}

\section{CONCLUSION}

This prospective analysis of Arsenicals used in Ayurveda medicine has given some light regarding the modern understanding of bioavailability, metabolism, toxicity, biological and pharmacological responses with the background of Ayurveda literature. Gouripasana (arsenic trioxide) is highly toxic compared to Haritala and Manashila.The bioavailability of Haritala and Manashila are low. Malla sindura and Rasa Manikya are two derivatives of White arsenic and Orpiment respectively used in certain cases of cancer and solid tumor by the contemporary Ayurveda Practitioners and traditional healers of North East India. Gouripasana (arsenic trioxide) has been a major breakthrough as a cure for human leukemias. Total arsenic content alone is not sufficient for evaluating the safety of Arsenic containing Ayurveda medicine, the detailed bioavailability of individual formulation and risk/benefit should be considered for safety evaluation.

\section{REFERENCES}

1. Barnes PM, Bloom B, Nahin R. Complementary and alternative medicine use among adults and children: United States, 2007. CDC National Health Statistics Report \#12. 2008.

2. Emma Lynch, Robin Braithwaite. A review of the clinical and toxicological aspects of 'traditional' (herbal) medicines adulterated with heavy metals, Expert Opinion on Drug Safety 2005;4(4): 769 778. http://dx.doi.org/10.1517/14740338.4.4.769 PMid:16011453

3. Gogtay NJ, Bhatt HA, Dalvi SS, Kshirsagar NA. The use and safety of non-allopathic Indian medicines. Drug Saf. 2002;25(14):1005-19. http://dx.doi.org/10.2165/00002018-200225140-00003

PMid:12408732

4. Saper RB, Kales SN, Paquin $J$ et al. Heavy metal content of Ayurvedaic herbal products. JAMA 2004;292 (23):2868-2872. http://dx.doi.org/10.1001/jama.292.23.2868 PMid:15598918

5. Panda AK, Jay Krishnan KT. Consumer demand on traditional Medicine in Chennai Rural. Aryavidyan 2006; XIX(3)

6. Thomas X, Troncy. Arsenic: a beneficial therapeutic poison - a historical overview. J. Adler Mus Bull. 2009;35(1):3-13.

7. Khandpur S, Malhotra AK, Bhatia V, Gupta S, Sharma VK, Mishra $\mathrm{R}$, Arora NK. Chronic arsenic toxicity from Ayurvedic medicines. Int J Dermatol. 2008;47(6):618-21 http://dx.doi.org/10.1111/j.13654632.2008.03475.x PMid:18477160

8. Satpute AD. Rasa Ratna Samuchaya of Vagbhatta.trans. Varanasi, India: Chaukhamba Sanskrit Pratishtana;2003.

9. Shastri K. Rasa Tarangini of Sadananda Sharma.trans. New Delhi, India: Motilal Banarsidas; 1979.

10. Treleaven J, Meller S, Farmer P, Birchall D, Goldman J, Piller G. Arsenic and Ayurveda.- Leuk Lymphoma. 1993;10(4-5):343-5 http://dx.doi.org/10.3109/10428199309148558 PMid:7693104

11. Klaassen CD. Heavy metals and heavy-metal antagonists. In: JG Hardman, AG Gilman and LE Limbird (eds.), Goodman \& Gilman's The Pharmacological Basis of Therapeutics, pp. 1649-1672. New York: McGraw-Hill, 1996.

12. Zhang P, Wang SY and Hu XH. Arsenic trioxide treated 72 cases of acute promyelocytic leukemia. Chin. J. Hematol., 1996;17: 58-62

13. Waxman S, Anderson KC. History of the development of arsenic derivatives in cancer therapy. Oncologist. 2001;6(suppl.2):3-10. 
http://dx.doi.org/10.1634/theoncologist.6-suppl 2-3 PMid:11331434

14. Miller WH Jr, Schipper HM, Lee JS, Singer J and Waxman S. Mechanisms of action of arsenic trioxide. Cancer Res 2002;62:3893-3903. PMid:12124315

15. Meek WJ. The gentle art of poisoning, JAMA. 1955;158:335-339

16. Peggy A Oday. Chemistry and Mineralogy of Arsenic. Element, 2006;2(2):77-83. http://dx.doi.org/10.2113/gselements.2.2.77

17. Raghu KG, Yadav GK, Singh R, Prathapan A, Sharma S, Bhadauria S. Evaluation of adverse cardiac effects induced by arsenic trioxide, a potent anti-APL drug. J Environ Pathol Toxicol Oncol. 2009;28(3):241-52 http://dx.doi.org/10.1615/JEnvironPathol ToxicolOncol.v28.i3.60 PMid:19888912

18. Vahter M. Effects of Arsenic on Maternal and fetal Health. Annu Rev Nutr. 2009;29:381-399 http://dx.doi.org/10.1146/annurev-nutr080508-141102 PMid:19575603

19. Panda AK, Misra S, Mohapatra SK. Iron in Ayurvedic Medicine, Journal of Advances in Developmental Research 2011;2(2) : 287293

20. Chen Z, Chen GQ, Shen ZX, Sun GL, Tong JH, Wang ZY, Chen SJ. Expanding the use of arsenic trioxide: leukemias and beyond.
Semin Hematol. 2002;39(2 Suppl 1):22-6 http://dx.doi.org/ 10.1053/shem.2002.33611 PMid:12012319

21. Jennie Treleaven, SimonMellar, Peter Farmer, Derek Birchall, John Goldman, Gordon Pillar, Arsenic and Ayurveda; Leukemia \& Lymphoma, 1993;10(4-5):343-345. http://dx.doi.org/10.3109 /10428199309148558 PMid:7693104

22. Leonidas C Platanias, Biological response to Arsenic Compounds, J Biol Chem. 2009;284(28):18583-7 http://dx.doi.org/10.1074 /jbc.R900003200 PMid:19363033 PMCid:2707240

23. T Sathya, B Murthy \& N Vardhini. Genotoxicity evaluation of certain Bhasmas using Micronucleus and Comet assays. The Internet Journal of Alternative Medicine. 2009;7(1)

24. Irshad shamin, Wadud Abdul, Johan Najeeb, Safi Ghulamuddin, Ahmad ghufran, Comparative toxicity study of various forms Sammuls far (As2O3) in mice, IJTK, 2011;10(4): 721-726.

Cite this article as:

Ashok Kumar Panda and Jayram Hazra. Arsenical compounds in Ayurveda medicine: A prospective analysis. Int. J. Res. Ayur. Pharm. $2012 ; 3(6): 772-776$ 